\title{
A Fundamentação Moral das Relações Internacionais Pré-jurídicas a partir de Kant*
}

Francisco Jozivan Guedes Lima**

\section{Introdução}

Este artigo tem como foco central de suas análises a pretensão de pensar as relações internacionais para além de um viés estritamente jurídico, distanciando-se, assim, de uma leitura positivista que vê nas leis estritas do direito a única solução para arbitrar as relações entre os Estados. A ideia basilar é que, anterior ao próprio estabelecimento do direito internacional, há uma esfera fundamental que é capaz de oferecer alguns critérios normativos básicos que orientem os Estados em suas vinculações: trata-se da moralidade pensada en-

\footnotetext{
* Artigo recebido em 9 de abril de 2012 e aprovado para publicação em 8 de janeiro de 2013.

** Doutorando em Ética e Filosofia Política pela Pontifícia Universidade Católica do Rio Grande do Sul (PUCRS). E-mail: jozivan2008guedes@gmail.com.
} 


\section{Francisco Jozivan Guedes Lima}

quanto condições mínimas por meio das quais os indivíduos, Estados e povos são protegidos e resguardados contra os abusos e diferentes tipos de violência.

O artigo prima pela minimização do jurídico e maximização do moral. O faz a partir de Kant, especificamente a partir da primeira seção de À paz perpétua (Zum ewigen Frieden, de 1795) (KANT, 2010). Nesse sentido, posiciona-se na anterioridade das análises que se concentram nos contributos dos artigos definitivos. Na análise de Henderson (2011, p. 144), "para Kant os artigos preliminares descrevem as condições mínimas que a razão exige como constitutivas de uma paz genuína". ${ }^{1}$ Eles foram configurados para lidar com a questão da guerra e da paz antes do estabelecimento do direito internacional. São basilares porque medeiam as relações interestatais ainda no estado de natureza.

Para Cavallar (1997, p. 79), esses artigos são imprescindíveis dentro da sistemática de À paz perpétua, porque "a paz preliminar ou provisória [Vorfrieden] ainda não exclui a guerra, mas proíbe determinados atos, que estão em contradição com a ideia de uma comunidade jurídica e, por conseguinte, com uma comunidade pacífica de povos livres". Segundo Nour, a estrutura de À paz perpétua não é uma novidade, pois mantém a similaridade com os tratados internacionais dos séculos XVII e XVIII: um tratado preliminar contendo as cláusulas negativas (proibições e condições para o fim da guerra); outro contendo as cláusulas positivas que expressam os acordos definitivos de paz; alguns suplementos que continham um artigo secreto e uma garantia; finalizando com dois apêndices (NOUR, 2004, p. XXVII). Os artigos preliminares são articulados por meio de proibições, utilizando-se na maioria das vezes do kein (nenhum) e do nicht (não). Como bem salienta Carl Friedrich (1962, p. 149),

Os seis artigos preliminares contêm as condições negativas do estabelecimento da paz entre os Estados: as proibições e as leis impostas aos 
Estados contratantes. Todos os seis artigos constituem a rejeição explícita das práticas existentes, em particular, das próprias práticas dos Estados monárquicos despóticos tal qual a Prússia.

Quanto à sua aplicabilidade, o próprio Kant (2010, p. 20) salienta que os artigos preliminares ( 1,5 e 6 ) são leis proibitivas ou estritas (leges strictae), que devem ser aplicadas de forma rígida, sem levar em conta as circunstâncias; e os artigos 2, 3 e 4 são leis permissivas ou latas (leges latae), que dependem das circunstâncias para sua aplicação, podendo até mesmo ser prorrogadas, mas nunca descartadas.

Na interpretação de Cavallar (1997, p. 82), "as leis permissivas possibilitam aplicar a lei do direito à realidade "no modo de uma reforma paulatina'. Elas assumem uma função de transição". Nesse ponto, esta pesquisa discorda de Cavallar: os artigos preliminares não podem ser artigos de transição porque são morais, pois seus pressupostos continuam valendo mesmo no direito internacional. Além do mais, voltam a vigorar caso haja um retorno ao estado de natureza numa eventual guerra.

\section{A Fundamentação Moral dos Artigos Preliminares a partir da Ideia de Liberdade}

No que diz respeito à fundamentação, os artigos preliminares são $a$ priori ou extraídos da experiência? São efetivados na experiência, na história, mas sua fundamentação se dá no nível da racionalidade. Cavallar e Nour também destacam a aprioricidade dos artigos preliminares. Nour (2004, p. 29) diz que as condições iniciais da paz trazem consigo pressupostos racionais indispensáveis, como a dignidade fundamental do ser humano e, entre outros, o primado da soberania estatal. 
A moral ocupa lugar imprescindível na filosofia prática kantiana, de modo que ela perpassa não só o nível da reflexão individual ${ }^{2}$ - o que a pesquisa ousar chamar de moral endógena -, mas constitui também condição para se pensar a fundamentação do direito, a relação com a política e com a própria filosofia da história, dimensões que a pesquisa ousar cognominar moral exógena. A moral é condição indispensável para todas essas dimensões porque está intimamente vinculada àquilo que há de mais profundo e valioso na filosofia prática de Kant, a saber, a liberdade.

A liberdade enquanto conceito moral é a faculdade suprassensível que põe em evidência o homem capaz de ações racionais (homo noumenon) ao invés de se limitar ao homem sensível e instintivo (homo phaenomenon). Limitar-se ao último implica o conflito não só em nível individual como também em nível interestatal. Daí a indispensabilidade moral que indivíduos e Estados saiam do estado de natureza e ingressem mediante um contrato (mediante uma confederação de Estados livres no nível internacional) numa condição jurídica de âmbito público: "Quando não podes te furtar a viver lado a lado com todos os outros, deves abandonar o estado de natureza e ingressar com eles num estado jurídico" (KANT, 2008a, § 42, p. 151).

Vale ressaltar que não há uma oposição abrupta entre estado de natureza e condição civil, mas uma relação de integração entre ambos. Para Bobbio (1992, p. 120), "O estado civil nasce não para anular o direito natural, mas para possibilitar seu exercício através da coação. O direito estatal e natural não estão numa relação de antítese, mas de integração."

Na Crítica da razão prática (Kritik der praktischen Vernunft, de 1788), a liberdade é entendida sob dois aspectos: a liberdade negativa, que consiste na independência de toda matéria da lei moral das circunstâncias empíricas e no afastamento dos obstáculos que impedem o exercício da liberdade; e a liberdade positiva, que implica a ca- 
pacidade de dar a si mesmo leis morais. Trata-se da liberdade enquanto autonomia (KANT, 2008b, n. 59, p. 55). Essa autonomia também é levada a sério no nível internacional no que se refere ao princípio da autodeterminação e soberania dos Estados, algo que demonstra a estreita conexão entre moralidade e relações internacionais.

\section{Em A religião nos limites da simples razão (Die Religion inner-} halb der Grenzen der bloßen Vernunft, de 1793), Kant afirma que "a moral baseada no conceito de homem, enquanto ser livre que por si mesmo se obriga, por sua razão, [...] não tem necessidade de um ser diferente, superior a ele para conhecer seu dever" (KANT, 2005, p. 11). Na análise de Eric Weil (1990, p. 27), o mérito de Kant foi ter firmado a tese de que "ser moral é determinar-se exclusivamente pela razão, agir unicamente por respeito à lei da razão". Trata-se, assim, da afirmação veemente da dignidade humana. Para Kant, "a autonomia é, pois, o fundamento da dignidade da natureza humana e de toda natureza racional" (KANT, 1974, p. 235). A dignidade humana consiste na capacidade de o sujeito ser legislador moral independentemente de diferenças empíricas.

A liberdade é uma ideia moral por excelência da filosofia prática kantiana. O direito entendido como "a soma das condições sob as quais a escolha de alguém pode ser unida à escolha de outrem de acordo com uma lei universal da liberdade" (KANT, 2008a, p. 76) não encontra sua fundamentação nos costumes contingentes, mas na própria racionalidade que se pretende a priori e universal, algo que só a moralidade (por ser embasada na ideia de liberdade como princípio universal) pode oferecer. Como bem salienta Joaquim Carlos Salgado (1986, p. 295), "a liberdade é o 'á' e o 'ù' da filosofia do direito de Kant; [...] o direito não existe por si e para si, mas para a liberdade".

A própria paz perpétua - que não é uma quimera como alguns podem vir a pensar, mas uma ideia regulativa da razão estrategicamente necessária para a consolidação da moral, do direito e da política e, con- 
sequentemente, para o progresso histórico da humanidade - constitui para o filósofo de Königsberg uma tarefa moral imprescindível a ser trabalhada dentro da história do gênero humano, que tem como protagonista o próprio homem entendido como fim terminal (Endzweck) da criação e, ipso facto, como único ser capaz de estabelecer a paz no mundo. Daí o autor falar em um "conceito de dever de paz perpétua" (KANT, 2010, p. 44). Sem esse dever moral basilar da promoção da paz mundial que impele os indivíduos ao estabelecimento de uma ordem jurídica, as relações internacionais ficariam sujeitas à arbitrariedade e ao realismo político, vindo a se fundar sobre interesses econômicos, aquisição e manutenção do poder. Destarte, a moralidade é um caminho que torna possível a existência de relações internacionais que se estabelecem para além de simples barganhas.

\section{Alguns Teóricos \\ Precedentes ao Projeto Kantiano para a Paz Perpétua}

Immanuel Kant não foi o precursor teórico de um projeto de paz. Anterior a ele, sobretudo na Modernidade, outros pensadores já tinham refletido acerca da guerra e da paz. Segundo Kersting (2004, p. 1), "a filosofia do Estado dos séculos XVII e XVIII era exclusivamente uma filosofia da paz". Dentre seus predecessores, pode-se brevemente citar: Dos índios e do direito de guerra, de Francisco de Vitoria (1963); O direito de guerra, de Alberico Gentili (2006); O direito da guerra e da paz, de Hugo Grotius (2005); Do direito de natureza e das gentes, de Samuel Pufendorf; Ensaio para se chegar à paz presente e futura na Europa, de Willian Penn; Projeto para tornar perpétua a paz na Europa, de Saint-Pierre (2003); Resumo do projeto de paz perpétua do senhor abade de Saint-Pierre de Rousseau; a carta de Leibniz a Grimarest de junho de 1712; Direito das gentes, do suíço Emer de Vattel; e Um plano para a paz 


\section{A Fundamentação Moral das Relações}

Internacionais Pré-jurídicas...

universal e perpétua, de Jeremias Bentham, o primeiro a usar a terminologia "International Law".

Antes de Bentham, era utilizado o termo "direito das gentes" (ius gentium) para designar o direito que se referia ao problema da guerra e da paz entre as nações. Além dessas produções teóricas, na prática, já em 1616, tinha sido criada em Heidelberg a cadeira de direito natural e direito das gentes dispensada por Espinosa e assumida por $\mathrm{Pu}-$ fendorf (TRUYOL, 1996, p. 17).

É óbvio que as especulações sobre a guerra se arrastam desde a Antiguidade. Em As leis, Clínias sustenta a tese de que "o que a maioria dos homens denomina paz, disso tem apenas o nome, pois em verdade, embora não declarada, é a guerra o estado natural das cidades entre si" (PLATÃO, 1980, p. 21). O Ateniense contra-argumenta a concepção nominalista de paz do seu interlocutor dizendo que o bom político ou legislador consciencioso é aquele que dispõe da guerra visando a paz, e não, pelo contrário, legisla em tempos de paz com os olhos fixos na guerra (PLATÃO, 1980, p. 24).

Essa mesma ideia do Ateniense é compartilhada por Cícero (106-143) e Agostinho de Hipona (354-430). Em De Officiis, Cícero (2009, p. 27) afirma que "a razão porque (e certamente por esta causa) deverão eclodir as guerras - que se possa viver em paz e sem injustiça".

No Livro XIX de A cidade de Deus, ao sustentar a tese de que a paze a vida eterna são as supremas aspirações dos seres humanos, Agostinho afirma que a paz é o verdadeiro fim da guerra, de modo que "o homem, com a guerra, busca a paz, mas ninguém busca a guerra com a paz" (AGOSTINHO, 2008, p. 399).

Na Modernidade, o tema ressurge com força. Refletindo sobre qual seria uma causa justa para se fazer a guerra (ius ad bellum), Vitoria (1963, p. 237) defende a tese de que "não é causa justa de uma guerra 


\section{Francisco Jozivan Guedes Lima}

a glória do príncipe, tampouco qualquer outra conveniência sua. A única causa justa para declarar a guerra é haver recebido alguma injúria". Essa ideia também foi defendida por Emer de Vattel, que vê na injúria a única causa legítima para a guerra (LOPES, 1999, p. 53).

Supostamente, Vitoria e Kant estariam de acordo quanto à ideia de que a deliberação sobre a guerra não decorre da decisão arbitrária de um príncipe ou de um monarca, mas que teria sua legitimidade a partir da coisa pública e da decisão dos súditos. Todavia, possivelmente estariam em desacordo quanto à questão em torno do papel da evangelização dos indígenas: a reflexão de Vitoria, sem sombra de dúvidas, tem o mérito de ir além dos limites da Europa, de alcançar o Novo Mundo; entretanto, leva consigo a prerrogativa de que a verdadeira religião a ser anunciada é a cristã, de modo que os espanhóis seriam justificados a impor, mesmo recorrendo à força, tal doutrina aos índios. Isso indubitavelmente é um abuso do qual Kant não compartilharia haja vista pensar a paz não sob justificativas religiosas e confessionais, mas filosóficas. Os artigos preliminares salvaguardam o pressuposto da não instrumentalização da dignidade humana, seja ela ligada ao indivíduo europeu, africano, asiático, americano etc. Algo que vai ecoar de modo veemente no seu Direito cosmopolita.

Cronologicamente um pouco posterior a Vitoria, Alberico Gentili tem uma concepção emblemática de guerra. Segundo o jurista italiano, "guerra é a justa contenda de armas públicas" (GENTILI, 2006, p. 61). Do seu ponto de vista, uma "guerra surda", ou em termos contemporâneos, uma "guerra fria", uma contenda de palavras, uma rixa ou luta entre cidadãos privados não qualifica um conflito como guerra. Para tal, um conflito deve ser público, as armas de ambas as partes beligerantes devem ser públicas e deve ocorrer entre duas partes iguais. Gentili (2006, p. 65) também defende que a guerra é feita pelos soberanos que devem ter autoridade suprema, de modo que "não há juiz na Terra para o príncipe e este não seria assim considerado se houvesse outro acima dele". 
Paradoxal em relação a Alberico Gentili, Hugo Grotius tem um conceito de guerra mais abrangente. Para ele, a guerra "é o estado de indivíduos, considerados como tais, que resolvem suas controvérsias pela força. Esta definição geral compreende todos os tipos de guerra [...]. Não exclui sequer a guerra privada [...] a mais antiga que a guerra pública" (GROTIUS, 2005, p. 72). Outro aspecto da teoria de Grotius que se pode ressaltar é a sua ideia de direito natural ancorado na razão. Segundo o jurista holandês, "o direito natural é tão imutável que não pode ser mudado nem pelo próprio Deus” (GROTIUS, 2005, p. 81).

Semelhante a Kant, a argumentação de Grotius para pensar o direito das gentes recebe sua justificação a partir do direito natural sustentado por bases morais, mas ambos os autores se distanciam no que diz respeito à fundamentação dessas bases: Kant as pensa enquanto fundamentadas na racionalidade secular; Grotius as concebe como vinculadas ao poder divino.

Já para Saint-Pierre (2003, p. 17), o problema da guerra na Europa só será resolvido quando for solucionado o problema dos Tratados entre os soberanos e sanado o desequilíbrio entre as Casas mais poderosas da Europa de seu tempo: França e Áustria. O filósofo francês propõe que seja criado um Sistema da Sociedade Europeia que "é um seguro impedimento contra as desgraças das guerras externas" (SAINT-PIERRE, 2003, p. 17). Na visão do abade, a paz se estenderia tão somente aos Estados cristãos europeus e dependeria da vontade dos soberanos. Segundo Roldán (1996, p. 138), Leibniz critica Saint-Pierre por abandonar o projeto de paz nas mãos dos príncipes, haja vista que os príncipes costumam, diz Leibniz, lutar contra as pestes e contra a fome, mas nunca visam o fim das guerras.

Já que Kant não fora o primeiro a propor um projeto de paz, qual seria, então, o diferencial do seu projeto perante os teóricos que lhe antecederam? Essa pesquisa indicará cinco possíveis diferenciais: (i)é 
um projeto universal, portanto não restrito a um determinado continente geográfico, à comunidade europeia, por exemplo; (ii) não se limita aos Estados cristãos, mas, pelo contrário, tem abrangência cosmopolita; (iii) não se fundamenta em elementos religiosos ou teonômicos, de modo que não se utiliza das Sagradas Escrituras para legitimar seus argumentos; ${ }^{3}$ (iv) é um projeto em que a paz não é decidida a partir da arbitrariedade de um monarca ou da vontade de uma determinada elite política (uma aristocracia), mas depende exclusivamente do consentimento dos cidadãos (concepção republicana de paz); (v) enfim, é um projeto (fundacional) que está embasado em pressupostos a priori morais.

\section{Os Artigos Preliminares enquanto Mediação das Relações Internacionais Pré-jurídicas: Do Tratado de Paz (Pactum Pacis) à Federação de Paz (Foedus Pacificum)}

O cerne do primeiro artigo preliminar está esboçado na seguinte advertência: "nenhum tratado de paz deve ser tomado como tal se tiver sido feito com reserva secreta de matéria para uma futura guerra" (KANT, 2010, p. 14). Segundo Gerhardt (1997, p. 40), o Tratado de Basileia celebrado entre a Prússia e a França em abril de 1795, ano da primeira publicação de À paz perpétua, teria sido o motivo externohistórico - a partir do qual Kant teria escrito seu projeto de paz.

Anterior ao Tratado de Basileia, alguns tratados já tinham despontado de forma emblemática no cenário europeu, como, por exemplo, os Tratados de Münster e Osnabrück, conhecidos como a "Paz de Westfália", celebrados em 1648, pondo fim à Guerra dos Trinta Anos (1618-1648). A partir de Westfália, as relações internacionais ganharam nova configuração: 


\section{A Fundamentação Moral das Relações}

Internacionais Pré-jurídicas...

Estabelece-se um pressuposto de reciprocidades, um direito internacional com pactos regulando relações internacionais, com a livre navegação nos mares e a busca do não comprometimento do comércio e dos civis na guerra. [...] As relações internacionais são secularizadas, ou seja, estabelecidas em função do reconhecimento da soberania dos Estados, independentemente de sua confissão religiosa (CARNEIRO, 2009, p. 184-185).

Alguns críticos, todavia, interpretam as relações internacionais westfalianas por um viés negativo. Catherine Audard (2006, p. 110) defende que o sistema westfaliano intensificou o recurso à guerra como solução dos conflitos entre os Estados soberanos devido à ausência de uma instância superior que mediasse tais litígios.

Em um caminho inverso do que Audard conjectura, esta pesquisa defende que os tratados westfalianos ofereceram uma grande contribuição para o direito internacional, a saber, a autonomização das relações interestatais perante a esfera religiosa. De fato, a partir daí paulatinamente os Estados tiveram que recorrer ao direito nos limites da razão para dirimir seus impasses, uma postura completamente compatível com a ideia kantiana de direito internacional.

A ideia fulcral de Kant no primeiro artigo preliminar é a de que um tratado perpassado por matérias que contêm elementos para uma futura guerra é, de saída, um tratado refutável do ponto de vista moral, já que porta em si os germes conflituosos. Em outras palavras, é autodestrutivo. O supracitado Tratado de Basileia constituiu um exemplo dessa reserva para futuras guerras, no sentido de que a Prússia foi contratualmente compelida a ceder parte de seus territórios para a França. No fundo, um incitamento ao conflito.

O tratado de paz ainda contém duas vulnerabilidades: (i) é paradoxal ao princípio da publicidade, já que é feito mediante reservatio menta- 
lis (intenção secreta); (ii) por ser um mero armistício, sua funcionalidade é tão somente provisória, de modo que, pela sua própria natureza, constitui a simples prorrogação das hostilidades.

Partindo do pressuposto de que a paz não significa a suspensão de um conflito, mas "o fim de todas as hostilidades", Kant propõe um dispositivo pacífico mais estável que o tradicional tratado de paz: trata-se da liga ou federação de paz, um instrumento do federalismo de Estados livres. A distinção fundamental é a seguinte: enquanto o tratado de paz (pactum pacis) põe fim a uma guerra, a federação de paz (foedus pacificum) postula colocar fim a todas as guerras, e para sempre (KANT, 2010, p. 34).

Nesse sentido, a função da foedus pacificum é garantir a conservação e a liberdade dos Estados que livremente se associaram a ela. Ela tem o dever de executar suas funções sem intervir na soberania dos Estados federados. Segundo Truyol (1996, p. 23), a federação de paz, mesmo sendo de caráter renunciável, já é superior ao simples pactum pacis.

\section{O Veto Moral à Instrumentalização do Estado: Uma Crítica ao Patrimonialismo Estatal}

A tese de Kant em defesa da não instrumentalização dos Estados é exposta no segundo artigo preliminar nos seguintes termos: "nenhum Estado independentemente (pequeno ou grande, isso tanto faz aqui) pode ser adquirido por um outro Estado por herança, troca, compra ou doação" (KANT, 2010, p. 15). Com isso, ele subverte e questiona o status quo de sua época, de modo específico as táticas moderno-colonialistas de anexação de territórios, dando, assim, um passo para além de sua época. 
Independentemente de sua extensão territorial, suas riquezas, seu potencial cultural etc., os Estados não devem ser instrumentalizados tal qual um objeto a ser vendido, comprado ou doado, em hipótese alguma. Esse é um princípio moral básico para as relações internacionais, sejam elas pré-jurídicas ou jurídicas.

Subjacente a isso, está a justificativa de que, no entender de Kant, o Estado, assim como os indivíduos, é revestido de caráter moral. Ele não tem preço, mas dignidade. O solo sobre o qual se funda é um patrimônio, mas sua natureza é em si mesma moral, haja vista ser fruto da ideia de um contrato originário que o revestiu de dignidade, tornando-se um bem público e, concomitantemente, inegociável. Ou seja, no âmago da sua legitimidade está o pressuposto contratualista de que ele resulta da anuência dos indivíduos (livres e capazes de ações morais), anuência esta configurada a partir do veto irresistível da razão prática, que do alto do seu trono normatiza a saída do estado de natureza e o estabelecimento de uma conditio iuris.Destarte, a instrumentalização do Estado implica de imediato não só a violação de sua soberania, como também a afronta à soberania do povo enquanto protagonista e titular da coisa pública. Isso aponta para o princípio da indissociabilidade entre Estado e cidadão, de modo que a instrumentalização de um viria a culminar na reificação do outro.

Cônscio desses pressupostos, Kant critica veementemente o velho costume das famílias reais europeias que se utilizam do casamento visando o acúmulo de territórios e o compartilhamento do poder sobre os Estados. Essa espécie de arranjo político que finda na negociação do Estado como uma simples mercadoria constitui uma anulação da "sua existência como uma pessoa moral [...] e contradiz, portanto, a ideia de contrato originário, sem o qual não se compreende nenhum direito sobre um povo" (KANT, 2010, p. 15).

O segundo artigo preliminar tem o mérito de romper com a concepção patrimonialista de Estado, incorporando assim, no cenário filo- 
sófico moderno, uma concepção personalista de Estado que o toma como uma pessoa moral. No entender de Soraya Nour (2004, p. 30): "O segundo artigo preliminar apresenta uma concepção personalista do Estado, tal como concebida pela Revolução Francesa, criticando a concepção patrimonialista, na qual se baseavam os procedimentos de transferência de soberania dos regimes saídos do feudalismo."

Essa crítica kantiana ao patrimonialismo estatal está clara na sua tese de que, mesmo em um reino hereditário, não é o Estado que é herdado, mas apenas o ato de governar: "o Estado adquire então um governante, não este como tal [...] o Estado" (KANT, 2010, p. 15). Essa tese é de fundamental importância não só para as relações internacionais - no sentido de que proíbe toda e qualquer tática imperialista de invasão e conquista violenta de Estados etc. -, como também para o direito civil interno, já que traz consigo a prerrogativa (o princípio pétreo) de que a coisa pública não seja açambarcada como patrimônio privado pelos governantes despóticos. Sem sombra de dúvidas, um importante dispositivo contra as possíveis corrupções e abusos que podem vir a acontecer no estado de direito.

\section{O Veto Moral à Instrumentalização do Indivíduo: Uma Crítica aos Exércitos Permanentes}

No terceiro artigo preliminar, Kant erige a seguinte tese em defesa da não instrumentalização dos indivíduos em guerras por parte dos Estados: "os exércitos permanentes (miles perpetuus) devem desaparecer completamente com o tempo" (KANT, 2010, p. 16). A ideia de fundo que sustenta essa normatividade está assentada no pressuposto de que os indivíduos são revestidos de moralidade, isto é, não são meros meios, mas fins em si mesmos, algo já posto de modo claro na Fundamentação da metafísica dos costumes (Grundlegung zur Metaphysic der Sitten, de 1785) por meio do seu imperativo 
prático da moralidade: "Age de tal maneira que uses a humanidade, tanto na tua pessoa como na pessoa de qualquer outro, sempre e simultaneamente como fim e nunca simplesmente como meio" (KANT, 1974, p. 229).

Em A metafísica dos costumes (Die Metaphysic der Sitten, de 1797), de modo mais específico na sua primeira parte que trata da doutrina do direito (Rechtslehre), o autor ratifica esse princípio da não instrumentalização do indivíduo, afirmando que, diferentemente dos vegetais e animais que são simplesmente usados como alimentação pelos indivíduos, o ser humano não pode ser usado como instrumento de guerra pelo Estado, haja vista ele ser fim em si mesmo e colegislador da coisa pública enquanto cidadão (KANT, 2008a, p. 188). Tal princípio constitui um veto moral aos Estados que ousam transformar seus súditos em homens-máquinas, degradando, assim, a humanidade inviolável que lhes é inerente.

A não instrumentalização do indivíduo é tão sacralizada na filosofia moral kantiana que serve como uma justificativa irrefutável para coibir a prática do suicídio. Na visão do autor, o suicídio é refutável porque, ao praticá-lo, usa-se a humanidade na sua própria pessoa como um mero meio, incorrendo-se assim numa espécie de autoinstrumentalização. A dignidade humana intrínseca a cada indivíduo prevê que "não posso dispor do homem na minha pessoa para o mutilar, o degradar ou matar" (KANT, 1974, p. 230).

Esse imperativo moral é levado a sério no que diz respeito às condições dos soldados na guerra. No geral, as guerras constituem uma afronta à dignidade humana, pois nela os indivíduos ficam na iminência de ser tratados como simples instrumentos de beligerância. Um exemplo dessa reificação é oferecida por Michael Stivelman ao referir-se à guerra de independência dos ucranianos perante os poloneses, em 1648, quando os cossacos da Ucrânia, de religião ortodoxa grega, massacraram judeus e católicos da Polônia. Os judeus que não 


\section{Francisco Jozivan Guedes Lima}

se converteram à religião dos cossacos foram trucidados de forma extremamente brutal:

Eram esfolados vivos e atirados aos cães; tinham seus membros decepados e atirados sob os cavalos; outros eram deixados sangrando até morrer; outros enterrados vivos; mulheres grávidas tinham seus ventres perfurados por espadas e adagas, o feto retirado e lançado sobre elas; os cossacos espetavam crianças em lanças, assavam-nas ao fogo e tentavam obrigar as próprias mães a comerem-nas; mulheres eram estupradas e mortas; muitos eram atirados ao rio para morrerem afogados (STIVELMAN, 2001, p. 32).

Historicamente, no que diz respeito a sua aplicabilidade, o terceiro artigo preliminar pode ser visto como uma crítica direcionada aos exércitos permanentes do tempo de Kant, sobretudo ao exército de Frederico II, que transformara a Prússia em uma grande potência bélica da época. Conforme ressalta Soraya Nour (2004, p. 31),

O exército permanente de Friedrich II dispunha de 230 mil homens, em uma população de seis milhões de habitantes. Nos tempos de paz, 70 a $80 \%$ dos rendimentos do Estado eram destinados à manutenção do exército; nos tempos de guerra, no mínimo 90\%, onerando a população camponesa com altos impostos. O Estado, a economia e a indústria eram militarizados. $\mathrm{O}$ exército era o instrumento de autoafirmação do Estado em suas relações exteriores e de sua força executiva nas relações internas [...].

De fato, como é frisado pelo próprio Kant ao longo do terceiro artigo, os Estados absolutistas europeus de seu tempo estruturavam seu poder a partir de três fortes mecanismos: armas, alianças estatais, dinheiro. Tratava-se, assim, de uma espécie de jogo pragmático, de um 
realismo político, em que o objetivo central é a manutenção do poder ao invés do cumprimento de normas morais.

Todavia, Kant confronta o uso dos exércitos permanentes no seu tempo, e de modo mais direto salienta que "ser mantido em soldo para matar ou ser morto parece consistir no uso de homens como simples máquinas e instrumentos na mão de um outro (o Estado), uso que não pode se harmonizar com o direito de humanidade em nossa própria pessoa" (KANT, 2010, p. 16). Sua proposta é que os exércitos permanentes sejam substituídos por um exército periódico voluntário constituído pelos próprios cidadãos. Nesse sentido, o exército deve ter funcionamento periódico e ser estabelecido mediante a própria vontade dos cidadãos por meio de alistamentos.

Na visão de Habermas, Kant teria criticado de modo veemente os exércitos permanentes, refutado os exércitos mercenários e exigido a instauração de exércitos nacionais; todavia, "não pôde prever que a mobilização maciça de jovens em serviço militar obrigatório, inflamados pelo sentimento nacional, ainda iria ocasionar uma era de guerras de libertação catastróficas e descontroladas, do ponto de vista ideológico" (HABERMAS, 2002, p. 193).

É possível que Habermas tenha incorrido em equívocos na sua interpretação, sob dois aspectos: (i) Kant propôs um exército voluntário e não uma espécie de serviço militar obrigatório; (ii) os exércitos periódicos voluntários não foram concebidos com a finalidade de empreender guerras de independência (Freiheitskriege), mas de zelar pela segurança dos próprios cidadãos e de sua pátria contra as agressões externas (KANT, 2010, p. 16). Nesse sentido, a proposta kantiana de um exército periódico voluntário como substitutivo dos exércitos permanentes tem como objetivo fundamental a formação de um exército defensivo ao invés de um exército ofensivo.

Enfim, poder-se-ia fechar esse artigo preliminar sintetizando três consequências negativas dos exércitos permanentes, a saber: (a) 
manter os exércitos permanentemente em prontidão para a guerra apenas incita os Estados a guerrear, provocando uma corrida armamentista, tornando, assim, a paz um sonho distante do real; (b) os exércitos permanentes geram custos maiores do que aqueles gerados em guerras com menor duração, onerando mais ainda os súditos, além de relegar as necessidades básicas do povo ao segundo plano; (c) em nível moral, os exércitos permanentes constituem uma afronta à dignidade humana, já que neles os indivíduos são usados como máquinas de guerra pelo Estado, algo incompatível com o imperativo prático da moralidade citado anteriormente.

\section{- Veto Moral ao Endividamento Bélico: Que as Verbas Sejam Investidas na Educação}

O quarto artigo preliminar é emblemático no que diz respeito ao endividamento dos Estados na guerra. A tese central é de que "não deve ser feita nenhuma dívida pública em relação a interesses externos do Estado" (KANT, 2010, p. 17).

Na interpretação de Bobbio, esse artigo se refere ao sistema de dívidas públicas introduzido pela primeira vez por Frederico III da Inglaterra. Com ele, Kant quis "evitar o perigo implícito do aumento indefinido da dívida pública, que leva o Estado a possuir uma perigosa força financeira, ameaça perpétua, direta ou indireta, de guerra" (BOBBIO, 1992, p. 161).

O acúmulo de fundos ou qualquer espécie de dívidas estatais (Staatsschulden) visando gastos em guerras constitui, na visão de Kant, uma ação inadmissível dentro do Estado republicano. Tal inadmissibilidade se reporta a três fatores precípuos: 
(i) nas relações internacionais pré-jurídicas - que ainda se dão no estado de natureza -, inexiste um sistema jurídico público que reja as relações comerciais interestatais, de modo que na guerra nenhum Estado está legitimado a emitir ou cobrar dívidas de outrem;

(ii) o endividamento visando o investimento em guerras pode levar o Estado endividado à falência, trazendo, assim, prejuízos a outros Estados (fiadores) e, ipso facto, criando um clima tenso nas relações interestatais, algo que pode indubitavelmente ocasionar conflitos e impossibilitar a paz; e

(iii) a dívida gerada na guerra, em última instância, recai sobre os cidadãos mediante imposições tributárias, mesmo que estes não tenham usufruído dos recursos provenientes do endividamento.

Para Kant, as dívidas estatais só são legítimas se forem geradas em prol da melhoria da infraestrutura, do crescimento econômico, do provimento dos armazéns para anos em que a colheita é escassa etc. O importante é que sejam perpetradas visando o bem comum dos súditos. Se cumprem tal objetivo, careceram de suspeição. Essa argumentação em torno da legitimidade das dívidas é bem visível em $\mathbf{O}$ conflito das faculdades (Streit der Fakultäten, de 1798), na Resposta à pergunta: que é o esclarecimento (Beantwortung der Frage: Was ist Aufklärung, de 1784) e em Ideia de uma história universal de um ponto de vista cosmopolita (Idee zu einer allgemeinen Geschichte in weltbürgerlicher Absicht, de 1784) (KANT, 1986), em que Kant tece duras críticas aos Estados que desviam investimentos para as guerras ao invés de destiná-los à educação dos súditos, especificamente à formação esclarecida acerca de seus direitos e deveres. Destarte, as dívidas estatais encontram sua legitimidade moral, sobretudo, quando direcionadas à formação de indivíduos críticos e autônomos. 


\section{Francisco Jozivan Guedes Lima}

\section{Em Ideia de uma história universal de um ponto de vista cosmo-}

polita, pode-se ler a seguinte crítica: "aos atuais governantes do mundo não sobra até hoje nenhum dinheiro para os estabelecimentos públicos de ensino [...] porque tudo está comprometido de antemão com as futuras guerras" (KANT, 1986, p. 21). O investimento em guerras ou o que o próprio Kant denomina "tesouro para a beligerância" impede o progresso do gênero humano, na medida em que compromete a educação moral e política dos indivíduos.

É necessário, portanto, que o Estado ofereça espaço aos cidadãos para que estes decidam através de seus representantes onde e como investir as verbas públicas. Nesse sentido, no estado de direito kantiano, o monarca não tem a prerrogativa de entrar numa guerra, endividar-se e, ao final da batalha, lançar a responsabilidade desse endividamento sobre os cidadãos, de modo que a decisão acerca da realização ou não da guerra caberá ao cidadão e não à arbitrariedade de um monarca.

O Veto Moral à Intervenção Interestatal e a Inviolabilidade do Princípio da Autodeterminação

No quinto artigo preliminar, Kant erige o princípio fundamental da não intervenção e da autodeterminação dos povos como um critério moral basilar para as relações internacionais. Sua tese é de que "nenhum Estado deve imiscuir-se com emprego de força na constituição e no governo de um outro Estado" (KANT, 2010, p. 18). A justificativa central é que a constituição e o governo de um povo não podem ser instituídos e consolidados mediante a violência ou o forçamento de potências externas. Pelo contrário, devem fluir livremente a partir do ato soberano do próprio povo. No entender da corrente contratualista, o estabelecimento de uma condição jurídica é o produto de um contrato celebrado mediante a anuência dos indivíduos, sob os auspícios da própria racionalidade que manda instituir um estado de direito. 
Conforme a tese supracitada, a intromissão não pode ser feita com o "emprego de força". Isso implica que é possível que haja intromissões, mas apenas de forma diplomática, pela via ideológica e dialógica, e não através do aviltamento físico ou da derrama de sangue.

Historicamente, o quinto artigo constitui uma crítica às potências colonialistas europeias que confundiam o direito de visita (Besuchsrecht) com o direito de conquista (Eroberungsrecht) e consecutivamente levavam todas as formas de opressão aos povos colonizados (KANT, 2010, p. 39).

De acordo com o princípio da autodeterminação pensado em termos morais kantianos, mesmo quando um Estado se desmembra em duas partes conflitantes entre si, chegando assim a uma anarquia, a intervenção não é legítima e constitui uma violação ao direito de um povo autodeterminar-se de modo autônomo:

Enquanto, porém, este conflito interno ainda não estiver decidido, esta intromissão de potências externas seria uma violação dos direitos de um povo que não depende de nenhum outro e que só luta contra seus próprios males; seria mesmo, portanto, um escândalo declarado e tornaria insegura a autonomia de todos os Estados (KANT, 2010, p. 19).

Como se pode depreender, o veto moral à intervenção interestatal e a inviolabilidade do princípio da autodeterminação dos povos estão fortemente ligados através do princípio da autonomia, autonomia esta que não remete só aos Estados, mas também aos povos. Nesse sentido, é possível que Otfried Höffe esteja equivocado ao afirmar que o direito das gentes kantiano não tem nada a ver com grupos étnicos e, portanto, não tem nenhum sentido antropológico e cultural, mas tão somente jurídico. Na sua concepção, o interesse de Kant "é exclusivamente direcionado ao 'direito dos Estados', não a 'gentes' no sentido de pessoa relacionada com o sangue, mas sim 'civitates', 
aqueles povos que no sentido de cidadãos são referidos na linguagem constitucional" (HÖFFE, 2006, p. 190).

Höffe teria razão na sua conjectura se Kant tivesse limitado seu projeto de paz apenas ao nível do direito internacional e, consequentemente, tivesse abandonado os pressupostos dos artigos preliminares e do direito cosmopolita. O próprio Höffe parece reconhecer essa sutileza quando afirma que o liberalismo político kantiano é marcado por um pluralismo tanto em nível nacional quanto internacional: "todas as pessoas e grupos têm direito a suas particularidades, ou até mesmo à convicção inabalável, sob a condição de que ela se comprometa a rigorosos princípios universais" (HÖFFE, 2006, p. 111).

Isso leva a crer que as relações internacionais em Kant não se restringem meramente ao direito internacional clássico, no sentido de que se comprometem tão somente com a inviolabilidade dos Estados. Atrelada a isso está também a inviolabilidade dos povos, ${ }^{4}$ de modo que, mesmo que um determinado povo não esteja reunido sob uma forma estatal e jurídica, como por exemplo, os povos indígenas no período colonial, os princípios da não intervenção e da autodeterminação dos povos, pensados em termos morais, proíbem que tal povo seja subsumido à condição de escravo e, concomitantemente, tenha suas terras invadidas e confiscadas.

\section{- Veto Moral à Guerra Punitiva, à Guerra de Extermínio e o Princípio da Mútua Confiabilidade Interestatal}

Semelhante aos indivíduos, no estado de natureza os Estados também estão numa situação de potencial conflito, de modo que a guerra está sempre na iminência de acontecer. Do ponto de vista do direito, na concepção de Kant, não há guerra justa no estado de natureza - 
não há ius in bello -, pois tal situação é perpassada pelo vácuo jurídico, ou seja, é carente de direito (Unrecht). Mesmo assim, do ponto de vista moral, os conflitos bélicos pré-jurídicos devem respeitar uma série de normas fundamentais que visam defender a integridade dos indivíduos, a autodeterminação dos povos, o princípio da não intervenção, a não instrumentalização dos Estados e outras normas já elencadas ao longo deste estudo.

O sexto artigo preliminar traz consigo a ideia basilar de que, mesmo na guerra, o elemento moral não pode desaparecer. Tal ideia está formulada por Kant nos seguintes termos: "nenhum Estado em guerra com outro deve permitir tais hostilidades que tornem impossível a confiança recíproca na paz futura; deste tipo são: emprego de assassinos, envenenadores, quebra de capitulação e instigação à traição no Estado em que se guerreia etc." (KANT, 2010, p. 19). Essas hostilidades constituem para Kant "estratégias desonrosas" ou "artes infernais" que privam os Estado de superar o estágio conflituoso.

O foco desse artigo preliminar é a manutenção, mesmo na guerra, da confiança recíproca na paz futura. A confiança constitui uma condição indispensável para que os Estados em guerra celebrem um contrato de paze, consecutivamente, ingressem numa condição jurídica.

Convém salientar que, anterior a Kant, Alberico Gentili, jurista italiano do século XVI, já defendia a proibição do envenenamento, da mentira, dos disfarces e de todas as demais estratégias desonrosas usadas na guerra. Para Gentili, a guerra pressupõe a justeza moral no combate, haja vista ser perpetrada entre duas partes iguais. Destarte, ele preconiza que "um príncipe que aspira ser justo deve, antes de tudo, ir à escola dos príncipes injustos para aprender o que se deve ou não fazer" (GENTILI, 2006, p. 250). Diferentemente de Kant, Gentili (2006, p. 452) defende a guerra punitiva, de modo que na sua concepção "o vencedor impõe de modo justo aos vencidos tributos e outros ônus". 


\section{Francisco Jozivan Guedes Lima}

Para Kant, a guerra punitiva (bellum punitivum) é contraditória porque no estado de natureza não há uma instância jurídica pública e imparcial que imponha sanções, penalidades, pagamentos de tributos etc. ao vencido. No estado de natureza interestatal, "não ocorre uma relação de um superior a um subordinado" (KANT, 2010, p. 19). Se houver uma relação de subordinação, essa só é possível mediante a força, mas a força não produz o direito.

O mesmo argumento vale em relação à guerra de extermínio (bellum internecinum). Tal guerra se caracteriza por implicar a destruição de uma das partes em conflito. Sua contradição está na seguinte argumentação: se no estado de natureza não há uma instância jurídica pública para regular os conflitos, "nenhuma das partes pode ser declarada como inimigo injusto (porque isto já pressupõe um veredicto judiciário)" (KANT, 2010, p. 19). Desse modo, nenhum Estado está legitimado a exterminar o outro; do contrário, a guerra de extermínio "possibilitaria a paz perpétua somente no grande cemitério do gênero humano" (KANT, 2010, p. 20).

Tanto a guerra de extermínio quanto a guerra punitiva são refutáveis não somente devido a uma argumentação tipicamente jurídica como a em que Kant parece incorrer, qual seja, a inexistência de uma condição jurídica de âmbito público, mas o são também moralmente refutáveis porque aniquilam, degradam e instrumentalizam (transformam em mero meio) o Estado, os indivíduos e os povos enquanto pessoa moral, isto é, enquanto individualidades livres e capazes de autodeterminação.

\section{Considerações Finais}

O fio condutor desta pesquisa consistiu em acentuar a relevância dos artigos preliminares para as relações internacionais pré-jurídicas. Tais artigos carregam consigo pressupostos morais fundamentais que perpassam tanto o direito internacional quanto o direito cosmopolita. Eles constituem a base de sustentação do projeto kantiano À 
paz perpétua. Sem eles, tal projeto ficaria restrito à mera positividade do direito ou ao simples realismo político.

Em um primeiro momento, foi esboçada a fundamentação moral dos artigos preliminares a partir da ideia de liberdade pensada no seu sentido negativo e positivo (enquanto autonomia). Em seguida, contextualizou-se o supracitado projeto na modernidade. Tentou-se, então, realçar a importância de Kant sob a justificativa de que ele teria produzido uma teoria de paz universal sem se pautar em justificativas teológicas, recorrendo, portanto, aos argumentos morais, jurídicos e políticos esboçados nos limites da racionalidade.

Em um terceiro momento, foram apresentados os artigos preliminares enquanto mediação das relações internacionais pré-jurídicas, demonstrando argumentações morais em defesa da federação de Estados livres, da não instrumentalização do Estado e do indivíduo, do não endividamento bélico, dos princípios da não intervenção e autodeterminação dos povos, culminando em uma análise sobre o princípio moral da mútua confiabilidade interestatal e em algumas reflexões sobre a guerra punitiva e a guerra de extermínio.

Enfim, a pesquisa sustentou a tese de que a moral é uma esfera fundamental capaz de oferecer alguns critérios normativos básicos que orientem os Estados em suas vinculações recíprocas: tratou-se, portanto, de pensar a moralidade enquanto condições mínimas através das quais os indivíduos, Estados e povos são protegidos contra os variados tipos de violência. Sua pretensão essencial foi a maximização da moral e a minimização do jurídico.

\section{Notas}

1. Esta e as demais citações de originais em língua estrangeira foram livremente traduzidas para este artigo. 


\section{Francisco Jozivan Guedes Lima}

2. A lei moral do imperativo categórico, expressa na Fundamentação da metafísica dos costumes, diz: "Age apenas segundo uma máxima tal que possas ao mesmo tempo querer que ela se torne lei universal” (KANT, 1974, p. 223).

3. Na interpretação de Adela Cortina (2005, p. 27), À paz perpétua de Kant se dá nos limites da razão, isto é, é um projeto noológico (vous).

4. É nesse sentido que John Rawls pensa o direito dos povos para além do direito dos Estados. Ele mesmo afirma que sua intenção basilar era "seguir o exemplo de Kant tal como esboçado por ele na Paz Perpétua (1795), e a sua ideia de foedus pacificum" (RAWLS, 2001, p. 12).

\section{Referências Bibliográficas}

AGOSTINHO. A cidade de Deus: contra os pagãos. v. 2. Trad. Oscar Paes Leme. 8. ed. Bragança Paulista: Editora Universitária São Francisco, 2008.

AUDARD, Catherine. Cidadania e democracia deliberativa. Trad. Walter Valdevino. Porto Alegre: EDIPUCRS, 2006.

BOBBIO, Norberto. Direito e Estado no pensamento de Immanuel Kant. 2. ed. Trad. Alfredo Fait. Brasília: UnB, 1992.

CARNEIRO, Henrique. Guerra dos Trinta Anos. In: MAGNOLI, D. (Org.). História das guerras. 4. ed. São Paulo: Contexto, 2009.

CAVALLAR, Georg. A sistemática da parte jusfilosófica do projeto kantiano à paz perpétua. Trad. Peter Naumann. In: ROHDEN, V. (Org.). Kant e a instituição da paz. Porto Alegre: UFRGS/Goethe-Institut, 1997. p. 78-95.

CÍCERO. Dos deveres (De officiis). Trad. Carlos Humberto Gomes. Lisboa: Edições 70, 2009.

CORTINA, Adela. El derecho a la guerra y la obligación de la paz. In: VÁSQUES, M. E. (Ed.). Filosofía y razón: Kant, 200 años. Valência: Universidad de Valencia, 2005. p. 25-44. 
A Fundamentação Moral das Relações Internacionais Pré-jurídicas...

FRIEDRICH, Carl J. L'essai sur la paix: sa position centrale dans la philosophie morale de Kant. In : WEIL, E. La philosophie politique de Kant. Paris: Presses Universitaires de France, 1962.

GENTILI, Alberico. O direito de guerra. Trad. Ciro Mioranza. 2. ed. Ijuí: Ed. Unijuí, 2006.

GERHARDT, Volker. Uma teoria crítica da política sobre o projeto kantiano à paz perpétua. Trad. Peter Naumann. In: ROHDEN, V. (Org.). Kant e a instituição da paz. Porto Alegre: UFRGS/Goethe-Institut, 1997. p. 39-53.

GROTIUS, Hugo. O direito de guerra. v. 1. Trad. Ciro Mioranza. 2. ed. Ijuí: Ed. Unijuí, 2005.

HABERMAS, Jürgen. A inclusão do outro: estudos de teoria política. Trad. George Sperber e Paulo Soethe. São Paulo: Loyola, 2002.

HENDERSON, Gordon P. Idealism, realism, and hope in Kant's perpetual peace. In: GERHARDT, V. (Org.). Kant und die Berliner Aufklärung: Akten des IX Internationalen Kant-Kongresses. Berlim: de Gruyter, 2011. p. 143-151.

HÖFFE, Otfried. Kant's cosmopolitan theory of law and peace. Nova Iorque: Cambridge University Press, 2006.

KANT, Immanuel. Fundamentação da metafísica dos costumes. Trad. Paulo Quintela. São Paulo: Abril Cultural, 1974.

Ideia de uma história universal de um ponto de vista cosmopolita. Trad. Rodrigo Naves e Ricardo Terra. São Paulo: Editora Brasiliense, 1986.

A religião nos limites da simples razão. Trad. Ciro Mioranza. São Paulo: Escala, 2005.

A metafísica dos costumes. 2. ed. Trad. Edson Bini. Bauru: Edipro, 2008a.

Crítica da razão prática. Trad. Valerio Rohden. São Paulo: Martins Fontes, 2008b.

À paz perpétua. Trad. Marco Zingano. Porto Alegre: L\&PM, 2010.

KERSTING, Wolfgang. Hobbes, Kant, a paz universal e a guerra do Iraque. Kant E-Prints, v. 3, n. 2, p. 1-13, 2004. 


\section{Francisco Jozivan Guedes Lima}

LOPES, José Alberto Azeredo. Textos históricos do direito e das relações internacionais. Porto: Universidade Católica Portuguesa, 1999.

NOUR, Soraya. À paz perpétua de Kant: filosofia do direito e das relações internacionais. São Paulo: Martins Fontes, 2004.

PLATÃO. Diálogos: Leis e Epinomis. v. XII-XIII. Trad. Carlos Alberto Nunes. Belém: Universidade Federal do Pará, 1980.

RAWLS, John. O direito dos povos; seguido de A ideia de razão pública revista. Trad. Luís Carlos Borges. São Paulo: Martins Fontes, 2001.

ROLDÁN. Los “prolegómenos” del proyecto kantiano sobre la paz perpetua. In: ARAMAYO, R. (Org.). La paz y el ideal cosmopolita de la ilustración: a propósito del bicentenario de hacia la paz perpetua de Kant. Madri: Editorial Tecnos, 1996. p. 125-154.

SAINT-PIERRE, Abbé de. Projeto para tornar perpétua a paz na Europa. Trad. Sérgio Duarte. Brasília: Editora Universidade de Brasília, 2003.

SALGADO, Joaquim Carlos. A ideia de justiça em Kant: seu fundamento na liberdade e na igualdade. Belo Horizonte: Editora UFMG, 1986.

STIVELMAN, Michael. A marca dos genocídios. Rio de Janeiro: Imago Ed., 2001.

TRUYOL, Antonio. A modo de introducción: la paz perpetua de Kant en la historia del derecho de gentes. In: ARAMAYO, R. (Org.). La paz y el ideal cosmopolita de la ilustración: a propósito del bicentenario de hacia la paz perpetua de Kant. Madri: Editorial Tecnos, 1996. p. 17-29.

VITORIA, Francisco de. Las relecciones De indis y De iure belli. Washington: Unión Panamericana, 1963.

WEIL, Eric. Filosofia política. Trad. Marcelo Perine. São Paulo: Loyola, 1990. 


\section{A Fundamentação Moral das Relações Internacionais Pré-jurídicas...}

\section{Resumo}

\section{A Fundamentação Moral das Relações Internacionais Pré-jurídicas a partir de Kant}

Esta pesquisa pretende apresentar uma fundamentação moral para as relações internacionais pré-jurídicas a partir de Kant, especificamente a partir dos artigos preliminares de À paz perpétua. Esses artigos constituem as condições morais mínimas através das quais os indivíduos, os Estados e os povos são protegidos contra os abusos oriundos do estado de natureza. Sem eles, as relações internacionais ficam sujeitas ao direito positivo ou ao realismo político. Seus elementos morais constituem os princípios fundamentais através dos quais as relações internacionais em Kant têm sua legitimidade.

Palavras-chave: Relações Internacionais Pré-jurídicas - Moral - Kant Filosofia Política

\section{Abstract}

\section{The Moral Foundations of Pre-juridical International Relations Based on Kant}

This research presents the moral foundations of pre-juridical international relations based on the preliminary articles of Immanuel Kant's Towards Perpetual Peace. These articles establish the minimal moral conditions through which individuals, states and people are protected against the abuses of the state of nature. Without them, international relations are subject to positive law or to political realism. These moral elements make up the fundamental principles which, to Kant, constitute the legitimacy of international relations.

Keywords: Pre-juridical International Relations - Morality - Kant Political Philosophy 